\title{
The Risks of Global Heating to Energy Systems and Energy Security
}

\author{
Larry Hughes ${ }^{1}$ and Moniek de Jong ${ }^{2, *} *$ (D) \\ 1 MacEachen Institute for Public Policy, Dalhousie University, Halifax, NS B3H 4R2, Canada; \\ larry.hughes@dal.ca \\ 2 Department of Political Science, Ghent University, B-9000 Ghent, Belgium \\ * Correspondence: Moniek.dejong@ugent.be
}

check for

updates

Citation: Hughes, L.; de Jong, M The Risks of Global Heating to Energy Systems and Energy Security. Sustainability 2021, 13, 10308. https:/ / doi.org/10.3390/su131810308

Academic Editor: Oz Sahin

Received: 3 August 2021

Accepted: 10 September 2021

Published: 15 September 2021

Publisher's Note: MDPI stays neutral with regard to jurisdictional claims in published maps and institutional affiliations.

Copyright: (c) 2021 by the authors. Licensee MDPI, Basel, Switzerland. This article is an open access article distributed under the terms and conditions of the Creative Commons Attribution (CC BY) license (https:/ / creativecommons.org/licenses/by/ $4.0 /)$.

\begin{abstract}
As recent events have shown, global heating is increasing the risk to many sectors of society, from agriculture to the built environment, to transportation. The energy security of most energy systems, regardless of their size, is also at risk from the effects of global heating: The reliable supply of power to end users can be threatened by extreme weather events affecting transformers and transmission and distribution networks. It can also be a threat to generators that are vulnerable to unpredictable supplies of water, such as thermal or hydroelectric generation facilities. In this paper, we use an energy security methodology to examine some of the possible climate risks to the supply of power from hydroelectricity produced by one of western Canada's electricity suppliers. The work is of particular interest because it shows how the increasing number of heatwaves that are affecting parts of western Canada and the Pacific Northwest could affect electricity supply in some western Canadian provinces and northern U.S. states.
\end{abstract}

Keywords: climate emergency; climate change; hydroelectricity; glaciers; drought; sustainability; energy risk assessment; climate emergency; Canada

\section{Introduction}

The 2021 heatwave and subsequent forest fires that raged across much of the Pacific Northwest of the United States and British Columbia in Canada led to hundreds of excess deaths and millions of dollars of property damage [1,2]. The lack of soil moisture coupled with the heatwave [3], both exacerbated by global heating, is intensifying the call to reduce global greenhouse gas emissions $[4,5]$.

The relationship between the increasing concentrations of atmospheric greenhouse gases and energy security is one aspect of global heating that has not gained public attention to the degree that heatwaves and forest fires have.

Energy security can mean different things to different people. Consumers of energy products view energy security as a reactive event, becoming an issue only if there is a shortfall in supply or the price of the supply increases. To those responsible for the entities supporting the energy system, energy security is proactive, requiring the system to be designed so that it is resilient, minimizing the availability and affordability risks to the consumers [6].

In this century, one set of risks that will become increasingly important will be the threat of global heating and the vulnerabilities to the energy system and energy consumers to these threats [7]. This is in large part because most of today's energy systems were not designed to be resilient to the risks of global heating, such as extreme weather events, sea-level rise, droughts, and forest fires [8-10]; for example, in countries that rely on reliable supplies of water for power generation, such as cooling water in thermal power stations or predictable weather patterns for hydroelectricity [11].

However, the affordability of some countermeasures to adapt systems to global heating is facing opposition; for example, Republicans in the U.S. Congress are opposing legislation 
dealing with climate change [12]; fuel protects, such as the yellow vest riots in France, triggered by increased fossil fuel prices [13]; and the impact of energy efficiency policies on low-income households [14].

The risk of drought affecting anthropogenic systems, such as agriculture [15], often focuses on changes causing the loss of human life and property $[16,17]$. The risk to renewable energy systems from climate change have been examined, including the Colorado River Basin [18] and hydroelectricity in Colombia [19]; however, none propose a systematic model to assess the energy security risks [20-22]. Moreover, existing literature on risk assessment and energy systems is limited to specific parts or analytical levels of the system rather than the entire system (for example, see Gupta [23], Jun et al. [24], Sheik et al. [25], Ang et al. [26], and Zhang [27]), and research by Winzer on risks and energy security is limited to supply [28]. The method developed by Hughes et al. includes risks and energy security and does not have this limitation and claims to be applicable to the system as a whole as well as specific parts [29].

This paper proposes a set of energy security methods for the systematic analysis of global heating risks on energy systems. The first shows how an energy system can be decomposed into its fundamental processes responsible for converting, carrying, and storing energy. The second uses the International Energy Agency's definition of energy security to analyze the system, determine whether it is in a secure or insecure state, and show different policy actions. The third and final method uses the first two to assess the risks faced by an energy system given certain threats.

The objective of this research is two-fold. First, it probes the effectiveness of these methods to analyze risks to energy systems. Second, it explores the negative impact of climate change on renewable energy systems and the need to adequately address these negative impacts to reduce the risks to energy security. Renewable energy systems are usually considered a solution to climate change, but the negative impact on climate change of renewable energy systems is less frequently highlighted.

We apply these methods to assess one of the risks, notably drought, to the hydroelectric generation capacity of Manitoba Hydro's Nelson River Hydroelectric project (NRHP) in western Canada [30]. Canada is the world's third-largest producer of hydroelectricity and meets over two-thirds of its electrical demand from hydroelectricity [31]; however, Canada is also disproportionately affected by global heating, and the risks of climate change to its renewable energy sources, such as hydro, should not be underestimated [32].

For this analysis we will use data from Canada's Changing Climate Report [32], and the IPCC [33], to determine the risk of water shortages in Manitoba Hydro's power supply to its customers in Manitoba, exports worth almost $\$ 4$ billion to neighbouring provinces (Saskatchewan and Ontario) and U.S. states (Minnesota and Wisconsin) [34,35].

The remainder of this paper is organized as follows. In the next three sections, the various methods (energy-system analysis, application of energy security to the system, and the energy-security risk model) are discussed. This is followed by an application of the risk assessment method to the NRHP, the IPCC's scenarios, and projected changes in temperature and precipitation. We discuss the implications and uncertainties of, and ways of adapting to, these risks in the closing section.

\section{Methods}

In this section, we introduce the energy systems model, show how the energy systems model can be used with a set of energy security methods, and describe our energy security risk method.

\subsection{Energy Systems}

At its most basic, an energy system takes sources of energy and converts them into forms that can be carried to and consumed by its end-users. The system is part of a structure consisting of the energy system and the external entities that influence how it functions. 
An energy system and its entities can be represented using a context diagram such as the one shown in Figure 1.

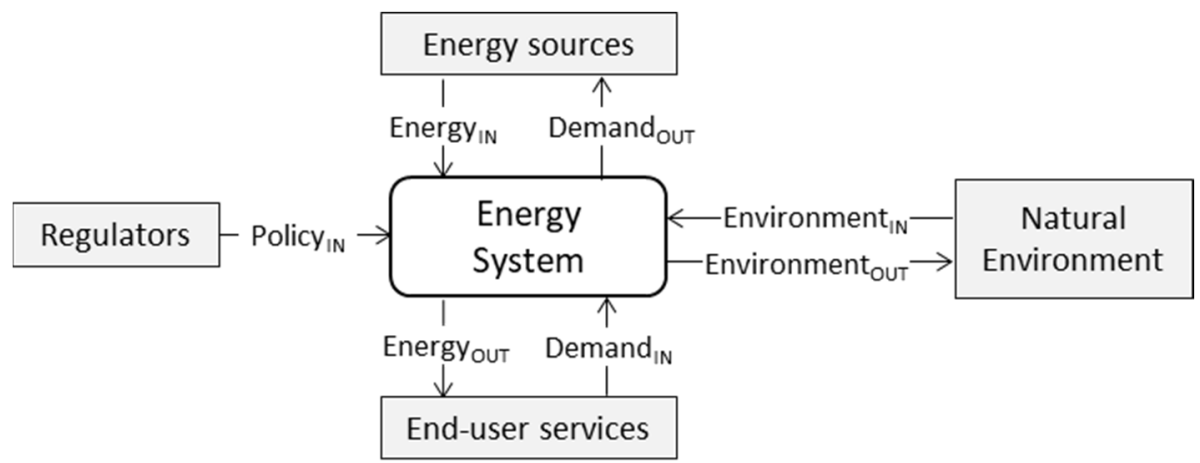

Figure 1. An energy system and its external entities [36].

The external entities (energy sources, regulators, natural environment, and end-user services) are outside the energy system's boundary (the solid line), meaning that the energy system has no control over their actions. The boundary can be shifted to include parts of the external entities or parts of the energy system can be included as part of an external entity. The boundary's position is determined by energy or policy analysts.

Each of the external entities interacts with the energy system. The labelled arrow (such as Policy ${ }_{I N}$ ) refers to what passes between the system and the external entity.

The four entities are defined as follows:

1. End-user services are the end user's energy-consuming services, sectors, or activities.

In general, this focusses on transportation, heating and cooling, and services that require electricity (such as appliances and lighting). The actual service depends on the definition of the end-user and the available datasets. For example, data published by the International Energy Agency (IEA) is aggregated at the national level and refers to the "final consumption" of three sectors (Industry, Transport, and Buildings) and "Other" (low energy-consumption sectors such as agriculture and fishing) [37]. Some datasets describe the energy demands within the services; the Residential Energy Consumption Surveys provided by the U.S. EIA are one such example, which includes descriptions of residential energy demand for air conditioning, water heating, appliances, electronics, and lighting, and space heating [38]. The Demand ${ }_{I N}$ flow refers to the type and quantity of energy that the service requires, while Energyout is the type, quantity, and cost of the energy supplied.

2. Energy sources are those supplies of energy the energy system requires to meet the energy demands of its end-user services. These depend on the context of the energy system, and can refer to primary energy found in nature (such as crude oil, coal, natural gas, biomass, and various renewables), secondary energy (energy converted from primary energy, such as natural gas to electricity), or secondary energy imported from a different energy system. Demand ${ }_{\text {OUT }}$ refers to the energy system's demand for a quantity of energy, while Energy $y_{I N}$ is the quantity and type of an energy source.

3. Natural environment refers to those parts of the earth's ecosphere that are affected by the actions of the energy system. Environment ${ }_{I N}$ refers to ecosystem services affected by the system, while Environment ${ }_{\text {OUT }}$ can be broken into air emissions, water emissions, and land emissions.

4. Regulators are those organizations (usually government or corporate) that determine the operational requirements of the energy system, issuing regulatory policies to the energy system (the Policy IN flows). Policy is often event driven, especially in terms of the energy system's interactions with the environment, such as $\mathrm{CO}_{2}$ emissions.

The energy system typically meets a wide variety of energy demands from its end users, such as refined petroleum products (transportation), natural gas (heating), and 
electricity (lighting). This means several things. First, the energy system cannot be a single monolithic entity, it requires subsystems (that is, processes internal to the system, often considered systems in their own right) to perform specific tasks. Second, each process must be able to handle the same flows the energy system does. Some of the flows will probably have different interpretations; for example, the regulatory policies for nuclear power plant operators will be different from those for wind-farm operators and the environmental emissions from pipelines are not the same as they are for electrical grids.

There are three types of process:

1. Convertor: A process that converts one form of energy to another (Figure 2). Primary energy sources are typically converted into secondary energy sources. Secondary sources can be converted into a form that meets the end users' needs. Since the process of conversion is never $100 \%$ efficient, there are always losses, which appear as Environment ${ }_{\text {OUT }}$ flows.

2. Carrier: A process that carries or transports energy from one place to another (Figure 3). The energy being carried is not changed (i.e., the energy is not being converted), although energy can be consumed when moving the energy or lost due to inefficiencies, or both. For example, a natural gas pipeline can use some of the natural gas in the pipeline to run the compressors moving the natural gas [39], while an electrical grid experiences heat, magnetic, and dielectric losses in the cables and transformers [40].

3. Storer: A process that stores energy to meet future demand (Figure 4), such as a fuel storage depot or a lithium-ion battery. The energy that is stored does not change; however, energy can be consumed moving the energy into and out of the storage and the energy can also be lost to the environment, for example, through evaporation or the loss of battery capacity over time.

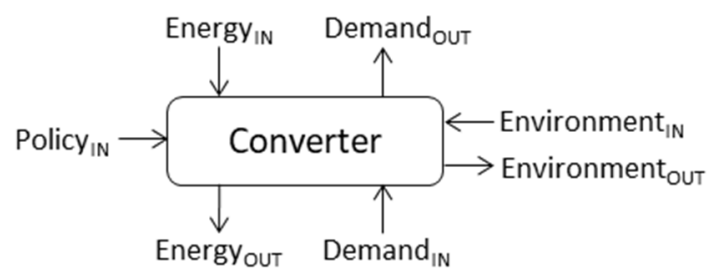

Figure 2. A convertor process.

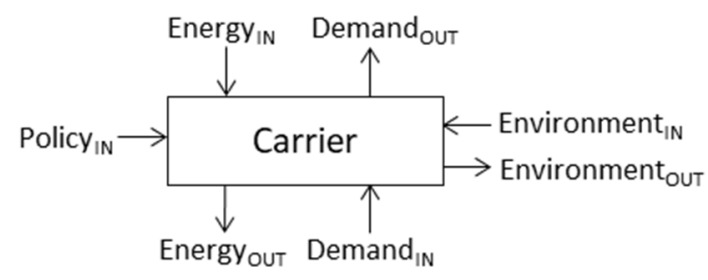

Figure 3. A carrier process.

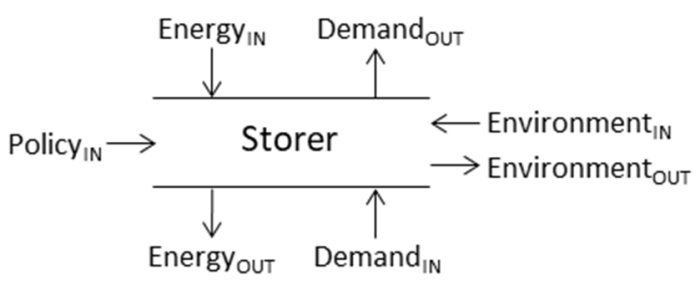

Figure 4. A storer process.

A simple energy chain representing some of the processes involved in supporting an end-user's electrical service requiring $10,000 \mathrm{kWh}_{\mathrm{el}}$ a year from a thermal (coal) generating facility is shown in Figure 5. 


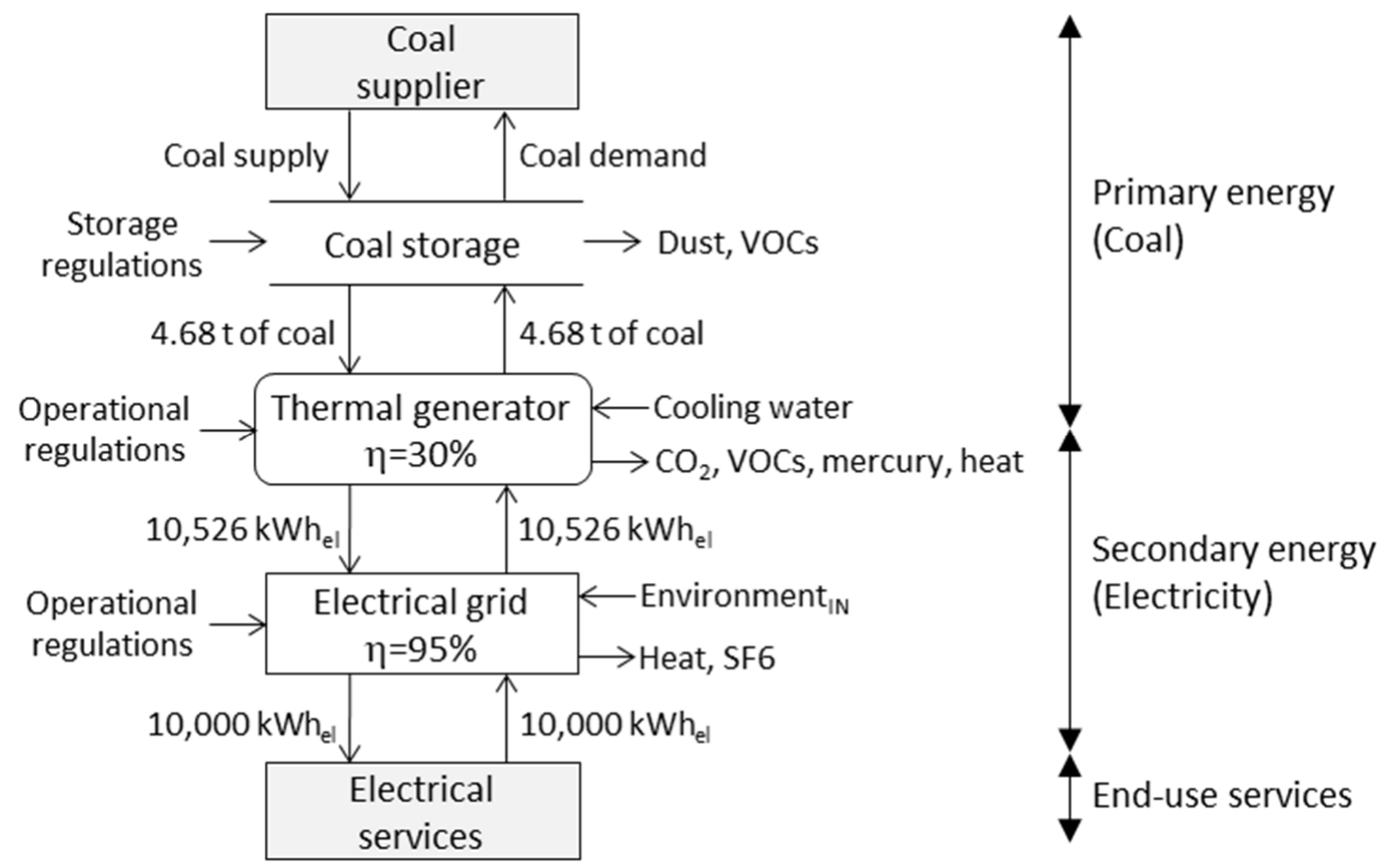

Figure 5. An example of an energy chain.

Each process in the chain passes its demand up the chain. Inefficiencies cause the demand to increase, ultimately requiring the thermal generator to produce enough electricity to both meet the demand and the losses from inefficiencies. Since the thermal generator is a conversion process, it requires coal from its coal storage. Each process is subject to regulations that are usually enforced by both the group responsible for the entity and the jurisdiction.

\subsection{Energy Security and Energy Systems}

There are many definitions of energy security [41]. One of the most straightforward is from the IEA, which defines energy security as "the uninterrupted availability of energy sources at an affordable price". We use the IEA's definition since it can be easily applied to the energy systems model and its various flows. In our energy security risk method, to be considered secure, an energy system must meet the energy demands of its end-users. Gracceva and Zeniewski [42] also indicate the importance of the energy system in energy security. This requires the energy supplied to the end-users to be:

1. Available, meaning the Energy IN $_{\text {flow }}$ equals the end-user's Demand OUT $_{\text {flow. If }}$ Energy $y_{I N}$ is less than Demand

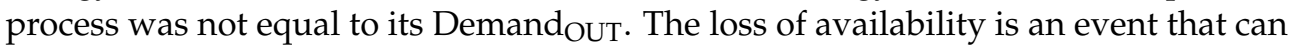
affect the energy security of an end-user, for example, the result of a storm damaging part of an electrical grid (electricity) or a refinery curtailing its output because of a fire (refined petroleum).

2. Affordable to the end-user. To be considered secure, the end-user's energy budget must be at least equal to the cost of the amount of the Energy IN consumed. If the energy cost exceeds the budget, an affordability event has occurred, where either the end-user's demand has increased, the cost of primary energy has increased, or the cost of one or more upstream processes (conversion, carrier, or storage) has increased. Affordability events that can affect an end-user's energy security include the introduction of carbon-pricing on emissions-intensive energy sources and a fuelprice rise caused by tensions in the Middle East. 
3. Acceptable to or meets a known standard. Although the acceptability of an energy flow is not part of the IEA's current definition of energy security (it was in an earlier version), it can be used to indicate the acceptability of the effects on the end-user of using Energy IN $_{\text {(such as health), breeches to Policy }}$ (these can be political, e.g., the burning of dung for heating or cooking), or a process' effects on Environment flow (such as mercury emissions from coal). If the flow meets the standard, it is considered acceptable; however, an event that results in the flow not meeting the standard is unacceptable and can be considered detrimental to energy security.

If all three conditions are met, the system can be considered secure and is said to be in its Normal state. However, if an event occurs that changes the availability, affordability, or acceptability of an energy flow, the stress on the end-user, the system, or both increases, causing it to enter an insecure stress state (see Table 1).

Table 1. Energy security dimensions, metrics, and states.

\begin{tabular}{|c|c|c|c|}
\hline Dimension & $\begin{array}{c}\text { Stress Metric } \\
\text { (Value of Stress) }\end{array}$ & Secure $($ Normal) State $($ Stress $=0$ ) & Insecure (Stress) State (Stress $>0$ ) \\
\hline Availability & $1-\frac{\text { Energy }_{I N}}{\text { Demand }_{\text {OUT }}}$ & Energy $_{\mathrm{IN}}=$ Demand $_{\mathrm{OUT}}$ & Energy $_{\text {IN }}<$ Demand $_{\text {OUT }}$ \\
\hline Affordability & $1-\frac{\text { Total energy budget }}{\text { Total cost of Energy IN }}$ & $\begin{array}{l}\text { Energy budget } \geq \\
\text { Cost of Energy }\end{array}$ & $\begin{array}{l}\text { Energy budget < } \\
\text { Cost of Energy }\end{array}$ \\
\hline Acceptability & Value in [Standard] & Value meets standard & Value does not meet standard \\
\hline
\end{tabular}

There are two stress states, determined by the level of the stress and its effect on the process or end-user (the entity). The level of stress at which the entity (or the system) is unable to operate is referred to as its Tipping Point. If the level of Stress $\geq 0$ and $\leq$ Tipping Point, the entity is in the Tension state; however, if the Stress > Tipping Point, it is in the Disruption state. The three different states and the conditions for changing states are shown graphically in Figure 6.

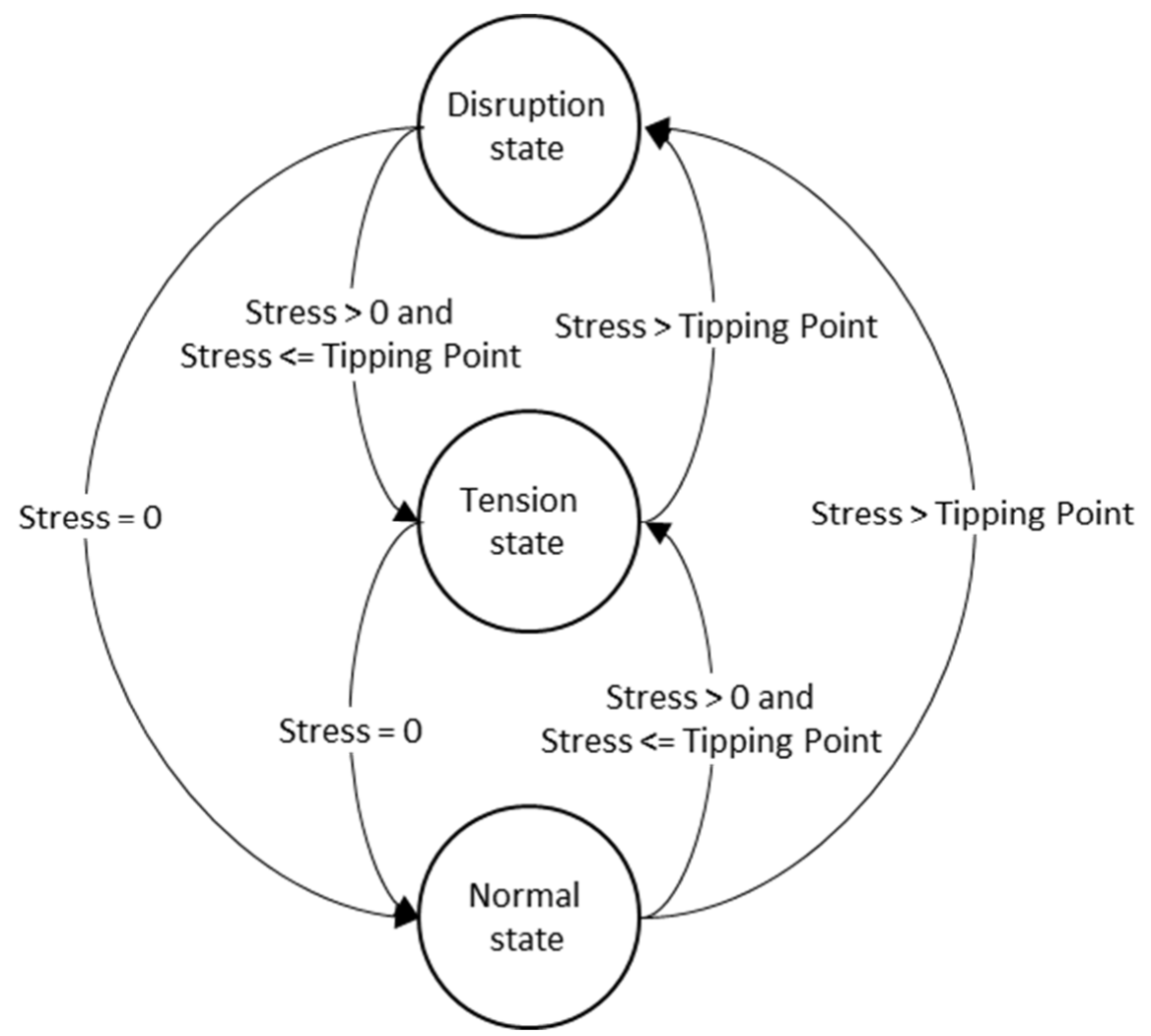

Figure 6. Possible entity or system states. 
The stresses and tipping points are specific to the dimensions of each entity. If the entity is in either the Tension or Disruption state, actions, referred to as countermeasures, are required to return it to its Normal state. Countermeasures that return an entity to the Normal state are said to be Resilient. The time taken to return to the Normal state is referred to as the Mean Time to Recover (MTTR) and the time between events is referred to as the Mean Time Between Events (MTBE). Short MTTRs and long MTBEs are usually considered tolerable, whereas the longer the MTTR or the shorter the MTBE, the more intolerable the event becomes to the entity.

If the entity is unable to return to its Normal state because the countermeasures for the event were inadequate or non-existent (making either MTTR or MTBE intolerable), the affected users of the entity might demand changes to it, resulting in a new Normal. These changes are referred to as an Adaptation and can be summarized by three actions intended to improve the energy security of an entity. Such actions are usually policy driven (see Table 2):

Table 2. Possible Adaptation actions.

\begin{tabular}{lccc}
\hline \multirow{2}{*}{} & & \multicolumn{2}{c}{ Entity or End-User Service } \\
\cline { 3 - 4 } & & Unchanged & Changed \\
\hline \multirow{2}{*}{ Type of Energy $y_{\text {IN }}$} & Unchanged & Reduction & Replacement \\
& Changed & Replacement & Restructuring \\
\hline
\end{tabular}

1. Reduction is any action that reduces energy demand without changing a process or end-user service. Reduction policies typically encourage those using an entity or energy-service to reduce their energy demand (Demand $\mathrm{IN}_{\mathrm{N}}$ ); the EnergyouT remains unchanged. Examples include financial incentives to reduce energy demand or pricing mechanisms to discourage energy use [43].

2. Replacement actions are intended to reduce energy demand by either changing the entity while still using its same Energy $y_{I N}$ (e.g., replacing a conventional vehicle with a hybrid-electric vehicle) or leaving the entity unchanged and changing its Energy $y_{\text {IN }}$ (replacing coal with co-fired coal and biomass in a thermal generating station).

3. Restructuring is a change to part of the energy system requiring both the entity and the type of Energy $\mathrm{IN}_{\mathrm{IN}}$ used to be replaced (e.g., shuttered thermal generation in favour of natural gas and renewables is an example of a restructuring [44]). Restructuring can also refer to the addition of new processes or end-user services and Energy IN $_{\text {to }}$ address an increase in demand (e.g., a consumer opting to buy electric vehicles rather than conventional petroleum vehicles). In either case, demand is met by new entities or end-user services and new Energy IN.

\subsection{The Energy-Security Risk Model}

In an energy system, if an event can put one or more entities into a stress state and affect an energy flow, then the energy system is said to be at risk from that event. An energy analyst can quantify the risks to an energy system using a risk analysis tool, such as the one by developed Hughes, de Jong, and Wang [29], which is built on the definitions of energy systems and energy security described above and uses five distinct steps to determine the risk of events to an energy system.

The method is generic, supporting the customization of assessment scales for specific entities, events, countermeasures, and tolerances, calculating the risk to an entity's or end-user's energy security:

1. Threats describe or define an event (a threat event). Threats can originate internally (accidental or structural), while external threat-events can change Energy IN $_{\text {(e.g., }}$ a terrorist attack), Demand IN $_{\text {(e.g., a surge in demand), Environment }}$ (including droughts or flooding), and Policy IN (carbon-pricing increasing the cost of energy).

2. Vulnerabilities define the vulnerabilities an entity can have to different threat-events. Each vulnerability can result in changes to one or more of the entity's flows and 
potentially affect the availability, affordability, and acceptability of these flows. In some cases, the entity is prepared for the threat-event and has countermeasures; the time taken to recover from the event is the MTTR, and those relying on the entity have a tolerance to it. The degree of each vulnerability can be expressed with qualitative or semi-quantitative values, such as low, moderate, or high. If the vulnerability can be measured quantitatively, this value can be used.

3. Impact determines the effect on the entity if a threat-event were to occur, given the entity's vulnerabilities. If the entity has adapted to the event, the entity would remain in its Normal state. However, if the threat-event increases the stress on the entity, it can enter the Tension state (impact is determined from its resilience and MTTR, a function of the countermeasures). If the stress exceeds the tipping point and the entity enters the Disruption state, there will be a significant impact on it.

4. Likelihood refers to the probability of a threat-event occurring; it is the MTBE and can be estimated quantitatively or qualitatively.

5. Risk is a function of the expected impact of the threat on an entity and the likelihood of it occurring.

\section{Case: Nelson River Hydroelectric Project}

We now consider some of the energy security risks to the availability of power if the water supply to the Nelson River Hydroelectric Project (NRHP) in northeastern Manitoba is affected by global heating. The province, located at the geographic center of Canada, generated over 99\% of its electricity from hydroelectric sources between 2008 and 2020 [45].

\section{Nelson River Hydroelectric Project}

In 2018, Manitoba Hydro had a total generating capacity of $5648 \mathrm{MW}$ [30], with over $90 \%$ being hydroelectric. Of its total capacity, more than three-quarters (about $4170 \mathrm{MW}$ ) are part of the NRHP (see Table 3). An additional $695 \mathrm{MW}$ of capacity will be added to the Project in 2021, with the completion of the Keeyask hydroelectric dam [46,47]. A further $3500 \mathrm{MW}$ is under consideration [48].

Table 3. Existing hydroelectric stations on the Nelson River [49].

\begin{tabular}{cccc}
\hline Generating Station & Year & Capacity (MW) & River \\
\hline Kelsey & 1961 & 287 & Nelson \\
Kettle & 1974 & 1220 & Nelson \\
Jenpeg & 1979 & 122 & Nelson \\
Long Spruce & 1979 & 980 & Nelson \\
Limestone & 1992 & 1350 & Nelson \\
Wuskwatim & 2012 & 211 & Burntwood \\
\hline
\end{tabular}

Three high-voltage DC (HVDC) transmission lines (each about $500 \mathrm{kV}$ and $2000 \mathrm{MW}$ ) run from two converter stations in the Nelson River hydroelectric development region to a converter station in southern Manitoba near Winnipeg. Manitoba Hydro generates electricity for both the provincial market and exports (both firm and non-firm sales) to neighbouring provinces (Saskatchewan and Ontario) and electricity suppliers in the United States [35].

The Project relies on water from the Nelson River watershed and the Churchill River

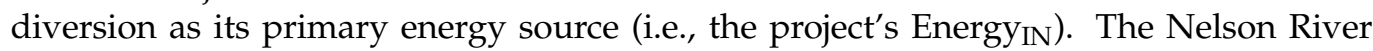
watershed (or basin) is the second largest in Canada, encompassing an area of over 1.1 million $\mathrm{km}^{2}$, and includes the Saskatchewan, Lake Winnipeg, Red River (including the Assiniboine River), and Winnipeg River basins. These basins drain into Lake Winnipeg, which flows north down the Nelson River, draining into Hudson Bay. The Churchill River diversion diverts most of the water flow of the Churchill River south to the Nelson River [50] (see Figure 7). 


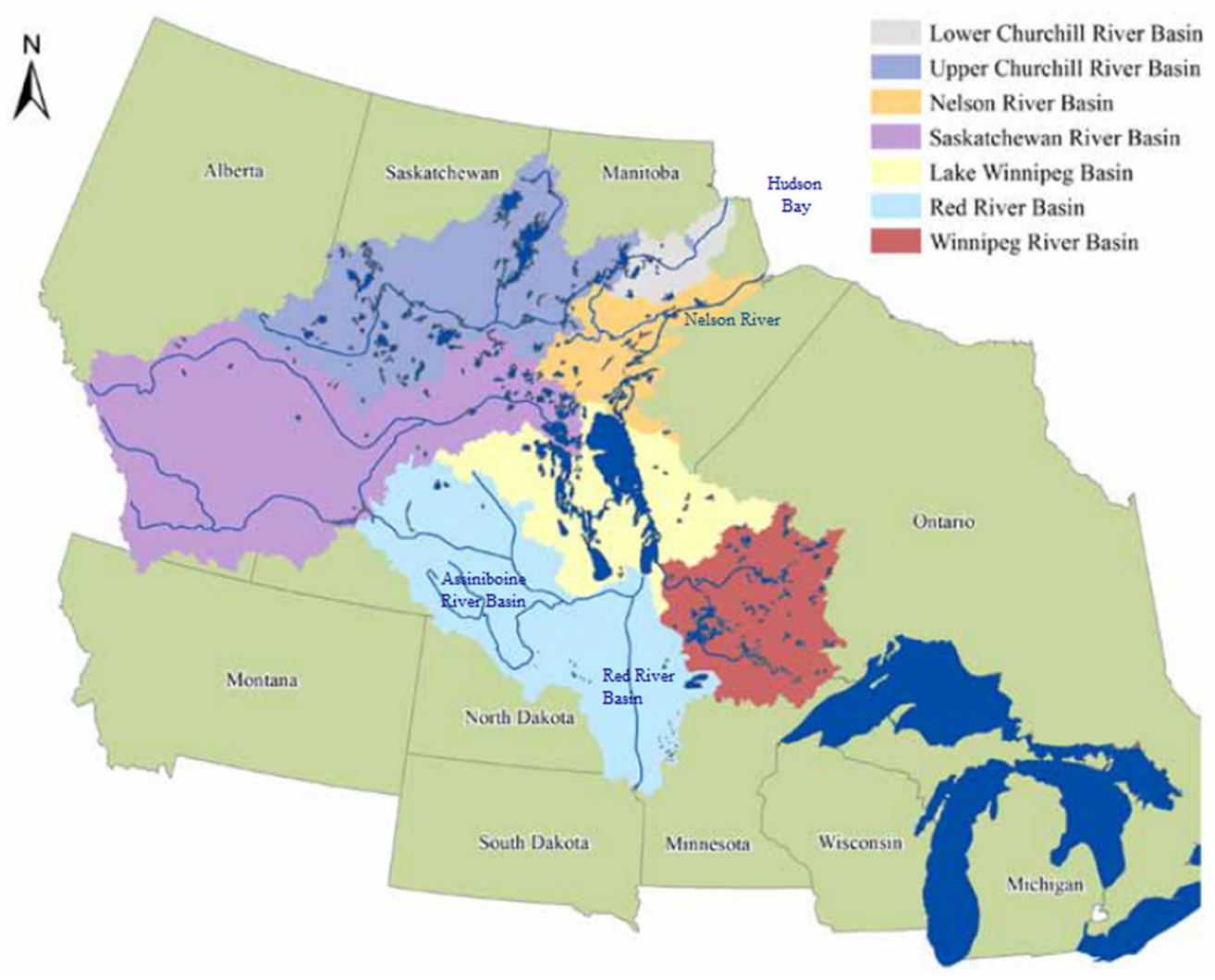

Figure 7. Nelson and Churchill River basins [48].

Lake Winnipeg, acting as a reservoir, stores about $60 \%$ of the project's mean annual energy [51] (see Table 4).

Table 4. Basins and their contributions to the Nelson River [50].

\begin{tabular}{cc}
\hline Basin & Contribution \\
\hline Saskatchewan River & $15.4 \%$ \\
Lake Winnipeg & $11.5 \%$ \\
Assiniboine River & $1.6 \%$ \\
Red River & $6.6 \%$ \\
Winnipeg River & $26.7 \%$ \\
Churchill River & $26.0 \%$ \\
Nelson River & $12.2 \%$ \\
\hline
\end{tabular}

Manitoba Hydro is responsible for regulating the levels of Lake Winnipeg, both to ensure it has sufficient capacity for hydroelectric production on the Nelson River and to reduce the flood risk to property owners on the lake. The power production range is 711 to 715 feet above sea level; if the level exceeds 715 feet, Manitoba Hydro maximizes the outflow of the lake [49]. However, reducing the level to below 715 feet would "compromise the reliability of the hydroelectric system in Manitoba and contribute to a decrease in net revenue arising from costs for new and modified facilities" [49], thereby increasing stress on the system.

Although regulation is attempting to keep Lake Winnipeg within the 711 to 715 feet limits, it is subject to the vagaries of nature. Figure 8 shows Lake Winnipeg's levels between 1915 and 2015; the dust bowl of the 1930s is apparent. 


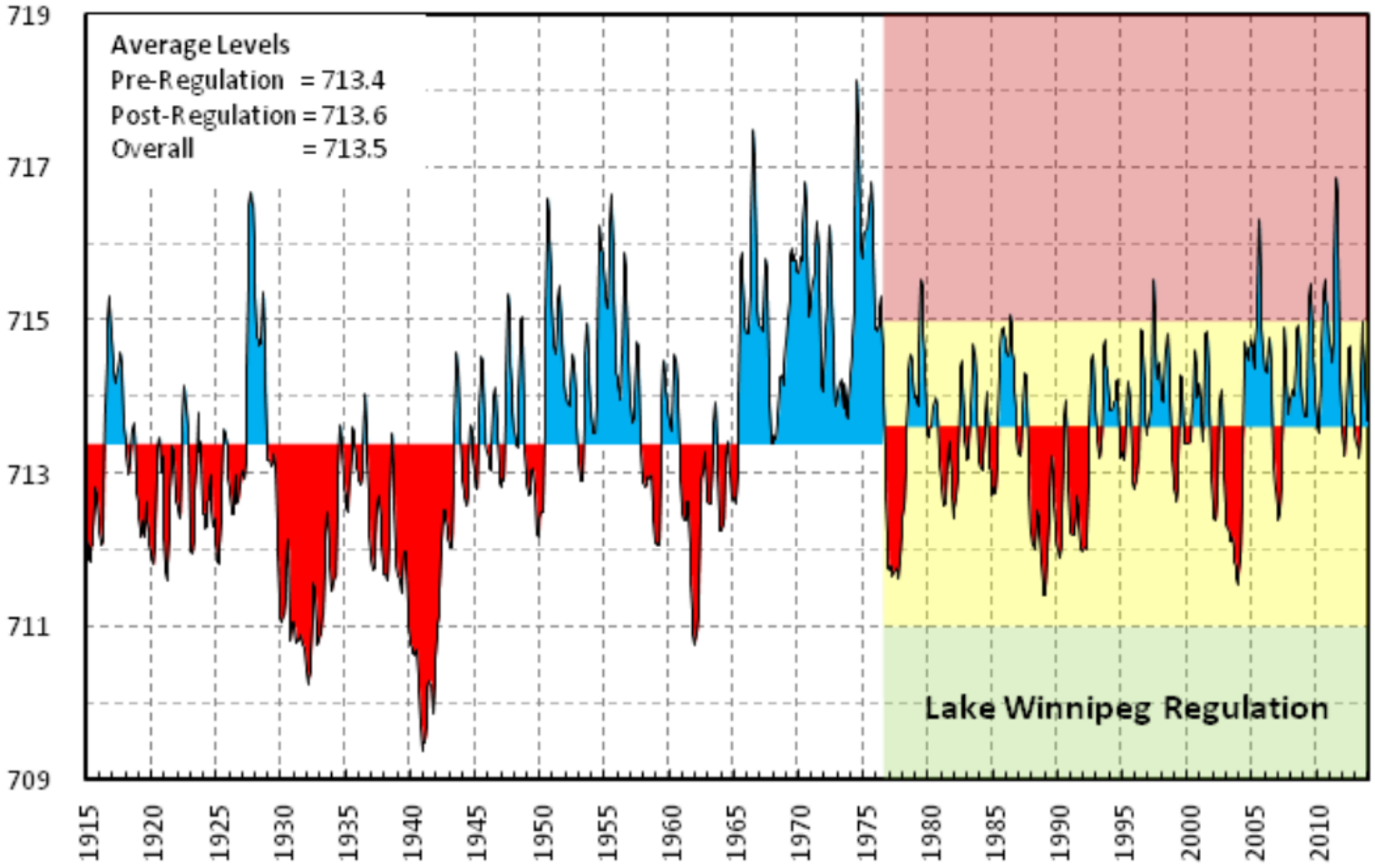

Figure 8. Lake Winnipeg water levels 1915 to 2013 [51].

As Figure 9 shows, droughts have occurred on the Prairies from at least the 15th century. Drought events in the Prairie Provinces are affected by El Niño Southern Oscillations [52].

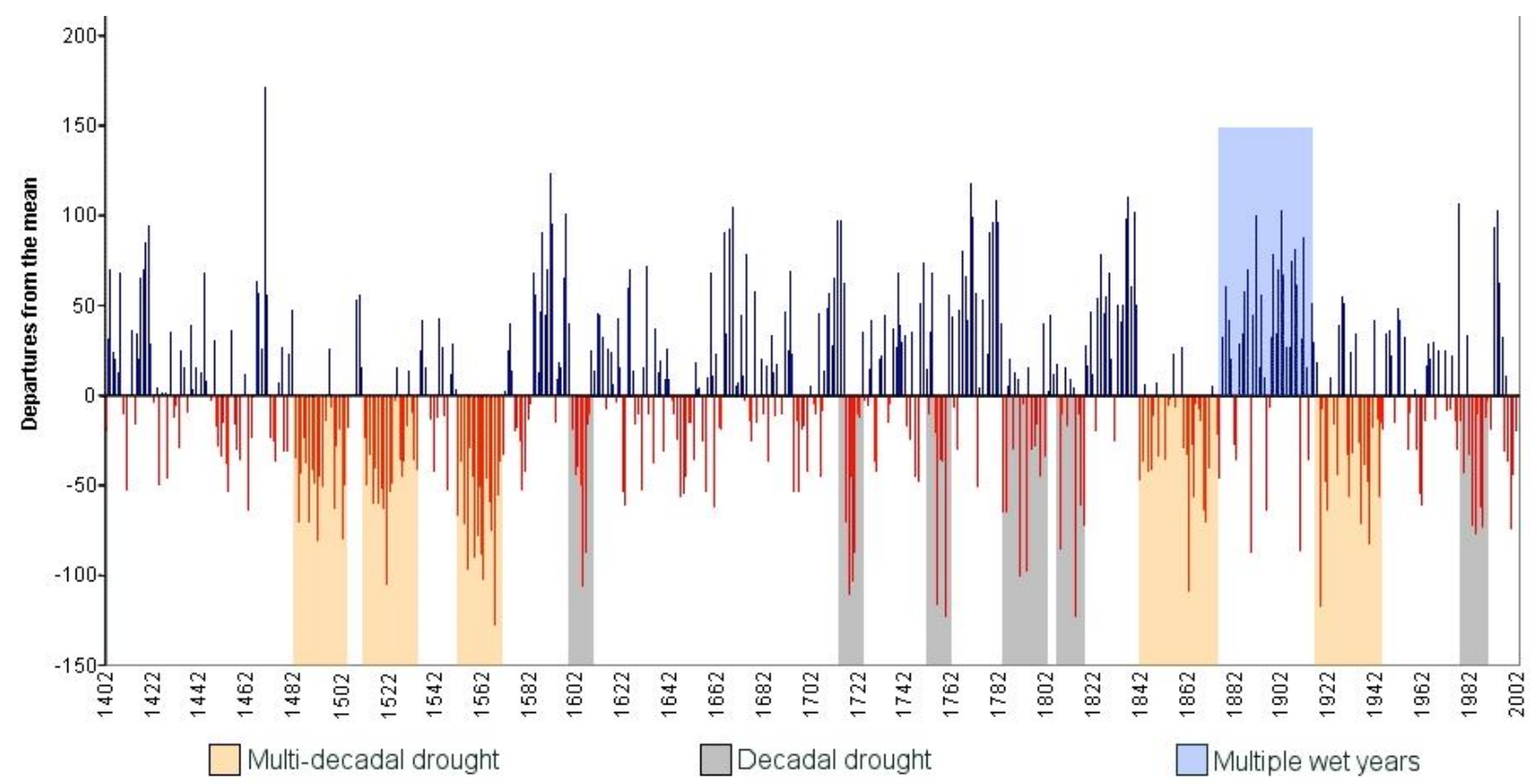

Figure 9. Drought frequency and severity for the Prairie Provinces (1402-2002) [53].

Relying on multiple basins can improve the reliability of the system. For example, in 2001, there was a major drought in Saskatchewan, which led to a decline in water from the 
Saskatchewan basin, and in 2003, both the Winnipeg River and Saskatchewan River basins experienced lower flows; in both cases, the lake's levels were affected [54,55].

\section{Results}

One of the most discussed climate change metrics is temperature rise [56,57]. A recent study by Environment and Climate Change Canada suggests that Canada will be disproportionately affected by global heating, as temperatures in Canada are rising at twice the global rate, and in the Canadian Arctic, at three times the global rate [32].

All energy systems will be at risk of global heating this century. Here we discuss the possible risks to the availability of electricity supply from Manitoba Hydro's NRHP.

\subsection{Background}

The IPCC's Representative Concentration Pathways (RCP) are a suite of scenarios describing different emissions pathways to 2100 [58]. RCP 2.6 is the most stringent pathway, with the lowest emissions and lowest radiative forcing of $2.6 \mathrm{~W} / \mathrm{m}^{2}$ (Watts per square metre), limiting global temperature rise to $2^{\circ} \mathrm{C}$ by 2100; this scenario is the most comparable to goals set out in the Paris Agreement in December 2015, while RCP 8.5 has the highest emissions and radiative forcing of $8.5 \mathrm{~W} / \mathrm{m}^{2}$. There are two intermediate scenarios, RCP4.5 and RCP6.0. The historic and projected emissions for each scenario are shown in Figure 10.

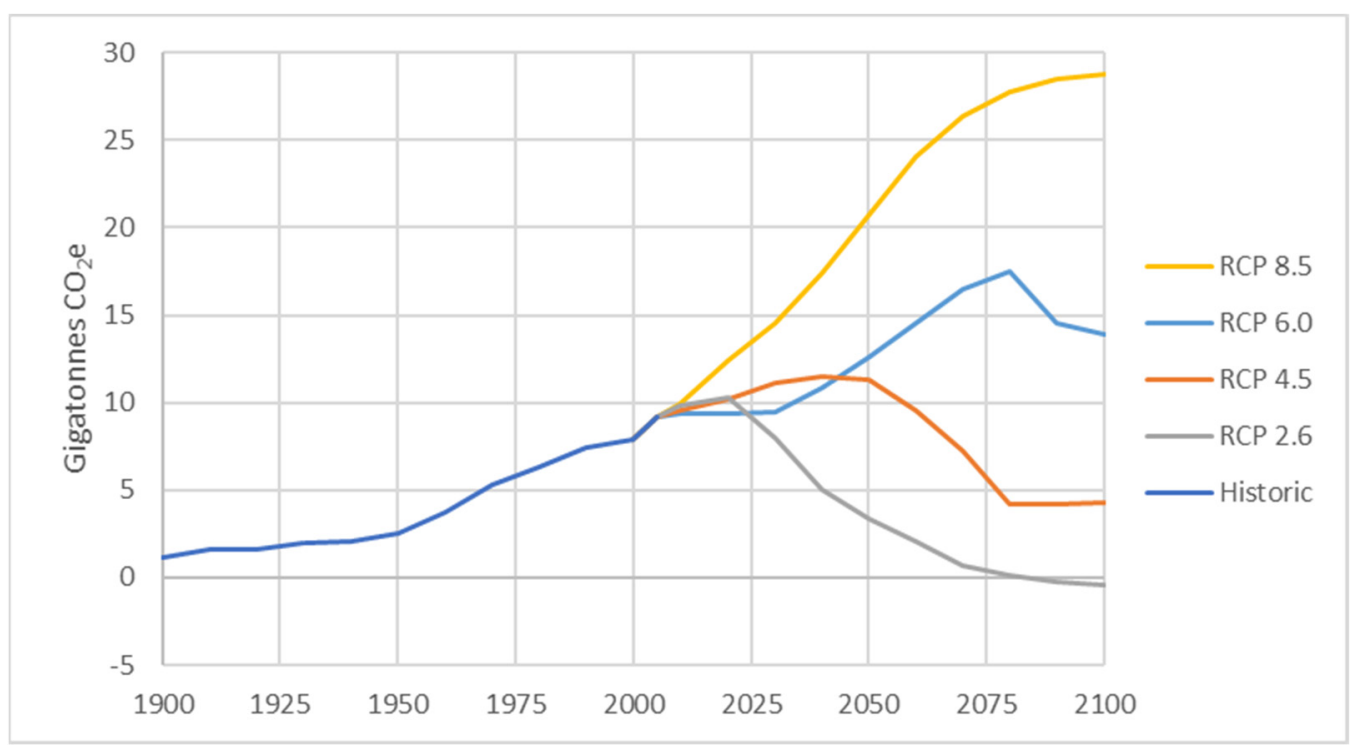

Figure 10. Representative Concentration Pathways (RCP) from 1900 to 2100 [59].

In keeping with the results from Canada's Changing Climate Report [32], we will examine RCP 2.6 and RCP 8.5.

\subsection{Threats}

Temperature: In Table 5, the modelled annual temperature change from CCCR for the Prairie region under the scenarios for the mid- and long-term are listed. The Prairie region consists of the provinces Manitoba, Saskatchewan, and Alberta. The annual changes do not reflect the seasonal difference, as the temperature increase during the winter months (December, January, and February) is expected to be higher than the increase in the summer months (June, July, and August). For both seasons, an increase in temperature is projected.

The projected temperature increases this century are expected to reduce glacier volumes by an estimated $40 \%$ to $60 \%$ by 2050 and $75 \%$ to $95 \%$ by 2100 in the Rocky Mountains [60]. As glaciers decrease in size, precipitation falling as snow is increasingly likely to accumulate on exposed surfaces, meaning there is no mechanism in place to keep the snow until late summer [61]. This will result in the snow melting earlier; although annual river 
flows may remain unchanged, it will occur earlier in the year [62], potentially requiring earlier water releases in Lake Winnipeg.

Table 5. Projected winter and summer changes in annual mean surface air temperature (relative to 1986-2005) for the Prairies in 2018 and 2100 [32] (pp. 132-135).

\begin{tabular}{cccccc}
\hline \multirow{2}{*}{ Region } & \multirow{2}{*}{ Season } & \multicolumn{2}{c}{ RCP 2.6 } & \multicolumn{2}{c}{ RCP 8.5 } \\
\cline { 2 - 5 } & & $\mathbf{2 0 3 1 - 2 0 5 0}$ & $\mathbf{2 0 8 1 - 2 1 0 0}$ & $\mathbf{2 0 3 1 - 2 0 5 0}$ & $\mathbf{2 0 8 1 - 2 1 0 0}$ \\
\hline \multirow{2}{*}{ All } & Annual & $1.5^{\circ} \mathrm{C}$ & $1.9{ }^{\circ} \mathrm{C}$ & $2.3^{\circ} \mathrm{C}$ & $6.5^{\circ} \mathrm{C}$ \\
\multirow{2}{*}{ Northern } & Winter & 1 to $2{ }^{\circ} \mathrm{C}$ & 1.5 to $2^{\circ} \mathrm{C}$ & 2 to ${ }^{\circ} \mathrm{C}$ & 7 to $9{ }^{\circ} \mathrm{C}$ \\
\multirow{3}{*}{ Southern } & Summer & 0.5 to $1{ }^{\circ} \mathrm{C}$ & 1 to $1.5{ }^{\circ} \mathrm{C}$ & 1.5 to $2{ }^{\circ} \mathrm{C}$ & 4 to $5{ }^{\circ} \mathrm{C}$ \\
& Winter & 1 to $1.5^{\circ} \mathrm{C}$ & 1.5 to $2{ }^{\circ} \mathrm{C}$ & 1.5 to $2{ }^{\circ} \mathrm{C}$ & 5 to $7{ }^{\circ} \mathrm{C}$ \\
& Summer & 1.5 to $1{ }^{\circ} \mathrm{C}$ & 1 to $1.5{ }^{\circ} \mathrm{C}$ & 1.5 to $2{ }^{\circ} \mathrm{C}$ & 4 to $5{ }^{\circ} \mathrm{C}$ \\
\hline
\end{tabular}

This will affect rivers in the Saskatchewan River Basin originating in Alberta's Rocky Mountains that rely on glacial snow melt to maintain their summer and late-summer river flows [63].

Temperature increases are also expected to affect evaporation, transpiration, groundwater, and snowfall (see below). All the Assiniboine River Basin and more than two-thirds of the Saskatchewan River Basin are within an area that is already prone to drought (see Figure 11).

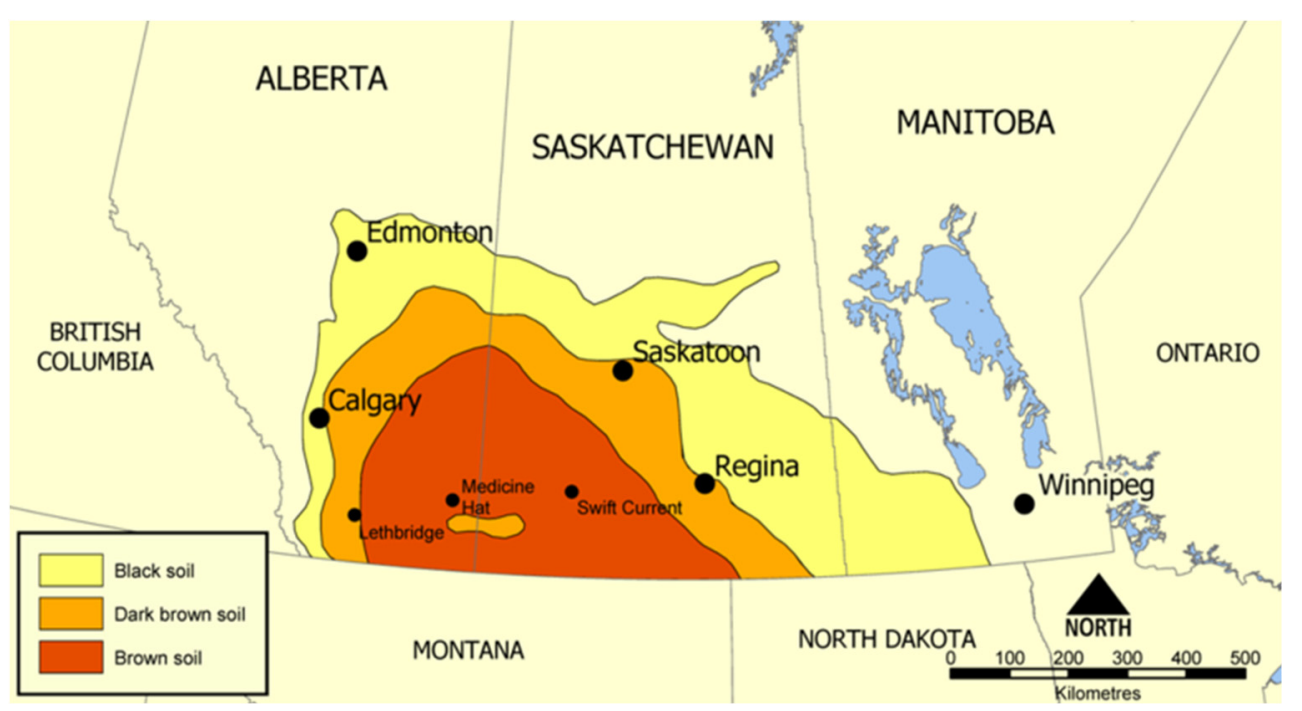

Figure 11. Drought-sensitive areas (Brown and dark brown soil areas) [64].

Precipitation: The second threat considered is to precipitation. Table 6 shows the projected changes in precipitation for the Prairie region for the mid- and long-term for both scenarios. Like the temperature increases, this trend has seasonal differences, with more precipitation expected in the winter than in the summer.

Table 6. Projected change in annual, winter, and summer precipitation, in percentage (relative to 1986-2005) for the Prairies [32] (pp. 161-163, 167).

\begin{tabular}{cccccc}
\hline \multirow{2}{*}{ Region } & \multirow{2}{*}{ Season } & \multicolumn{2}{c}{ RCP 2.6 } & \multicolumn{2}{c}{ RCP 8.5 } \\
\cline { 3 - 6 } & & $\mathbf{2 0 3 1 - 2 0 5 0}$ & $\mathbf{2 0 8 1 - 2 1 0 0}$ & $\mathbf{2 0 3 1 - 2 0 5 0}$ & $\mathbf{2 0 8 1 - 2 1 0 0}$ \\
\hline \multirow{2}{*}{ All } & Annual & $5 \%$ & $5.9 \%$ & $6.5 \%$ & $15.3 \%$ \\
\multirow{2}{*}{ Northern } & Winter & $0 \%$ to $10 \%$ & $0 \%$ to $20 \%$ & $10 \%$ to $20 \%$ & $20 \%$ to $40 \%$ \\
& Summer & $0 \%$ to $10 \%$ & $0 \%$ to $10 \%$ & $0 \%$ to $10 \%$ & $-10 \%$ to $10 \%$ \\
\multirow{2}{*}{ Southern } & Winter & $0 \%$ to $10 \%$ & $0 \%$ to $10 \%$ & $0 \%$ to $10 \%$ & $20 \%$ to $30 \%$ \\
& Summer & $-10 \%$ to $0 \%$ & $0 \%$ to $10 \%$ & $0 \%$ to $10 \%$ & $-10 \%$ to $0 \%$ \\
\hline
\end{tabular}


Snow on the Prairies is released slowly in the spring and contributes to groundwater. Rain during the winter months will runoff earlier, again potentially requiring earlier water releases. An earlier runoff and lack of precipitation during the summer months could affect hydroelectric generation in the late summer and fall.

Together, rising temperatures and increased precipitation have been shown to increase drought in the western U.S. [65]. Since southeastern Alberta and southern Saskatchewan are the northern limits to the U.S. Great Plains, the causes of droughts in the western U.S. can be expected to have similar effects.

\subsection{Threat-Events}

A decline in Lake Winnipeg's basin flows will increase the stress on the availability of the Nelson River project to meet demand. This will be driven by changes to temperature and precipitation that affect the Winnipeg River and Saskatchewan River basin flows, either seasonally or over several years. These are considered threat events.

Under the RCP 2.6 scenario, we assume that in both 2031-2050 and 2081-2100, an event would reduce basin flows by $20 \%$. In the RCP 8.5 scenario, we assume a 2031-2050 event would reduce flows by $20 \%$, whereas a $2081-2100$ event would reduce flows by $40 \%$. Table 7 lists the events and stress for each RCP scenario and period.

Table 7. Threat events and resulting stresses for RCP 2.6 and 8.5 for 2031-2050 and 2081-2100.

\begin{tabular}{ccccc}
\hline Threat Event & \multicolumn{2}{c}{ RCP 2.6 } & \multicolumn{2}{c}{ RCP 8.5 } \\
\cline { 2 - 5 } & $\mathbf{2 0 3 1 - 2 0 5 0}$ & $\mathbf{2 0 8 1 - 2 1 0 0}$ & $\mathbf{2 0 3 1 - 2 0 5 0}$ & 2081-2100 \\
\hline Seasonal flow decline in Winnipeg River Basin flows & Low & Low & Low & High \\
Multi-year declines in Winnipeg River Basin flows & Moderate & Moderate & Moderate & Very High \\
Seasonal decline in Saskatchewan River Basin flows & Very Low & Very Low & Very Low & Moderate \\
Multi-year declines in Saskatchewan River Basin flows & Low & Low & Low & High \\
\hline
\end{tabular}

\subsection{Vulnerabilities}

The NRHP is vulnerable to all the threat events listed and has countermeasures in place to handle such losses, either relying on in-house supplies, seasonal non-firm contracts, or multi-year firm contracts. Manitoba Hydro has no control over the duration of these events; the length of time the countermeasure is required is the MTTR, either six months (seasonal) or more than a year (multi-year). The tolerance reflects the degree of action required by the countermeasure to handle the event; its relationship to vulnerability is given in Table 8.

Table 8. Tolerance to vulnerability mapping.

\begin{tabular}{cccccc}
\hline Tolerance & Very Low & Low & Moderate & High & Very High \\
Vulnerability & Very High & High & Moderate & Low & Very Low \\
\hline
\end{tabular}

The threat events and their associated vulnerabilities are listed in Table 9. We assume that the need for firm and non-firm contracts for electricity becomes increasingly intolerable. The tolerance and vulnerability remain constant, regardless of the threat event's stress level.

Table 9. Threat events, countermeasures, and associated energy security indicators.

\begin{tabular}{|c|c|c|c|c|}
\hline Threat Event & Countermeasure & MTTR & Tolerance & Vulnerability \\
\hline Seasonal flows decline in Winnipeg River Basin & Rely on non-firm contracts & $<6$ months & Low & High \\
\hline Multi-year flows decline in Winnipeg River Basin & Rely on new, in-house supply or firm contacts & $>1$ year & Very Low & Very High \\
\hline Seasonal flows decline in Saskatchewan River Basin & Rely on short-term non-firm contracts & $<6$ months & High & Low \\
\hline Multi-year flows decline in Saskatchewan River Basin & Rely on new, in-house supply or firm contacts & $>1$ year & Moderate & Moderate \\
\hline
\end{tabular}




\subsection{Impact}

Based on the threat-event ranking and vulnerability, the impact of each threat event can be determined and assigned a stress state; one of Normal, Tension (Low, Moderate, and High), and Disruption. Table 10 lists the possible impacts, depending on the ranking of each threat event and the Manitoba Hydro's vulnerabilities. From the threat-event rankings (Table 7) and the different basins' vulnerabilities (Table 9), we use Table 10 to determine the impacts, listed in Table 11.

Table 10. Impact ranking.

\begin{tabular}{|c|c|c|c|c|c|c|}
\hline & & \multicolumn{5}{|c|}{ Threat-Event Ranking } \\
\hline & & Very Low Stress & Low Stress & Moderate Stress & High Stress & Very High Stress \\
\hline \multirow{5}{*}{ Vulnerability } & Very Low & Normal & Normal & Normal & Low tension & Moderate tension \\
\hline & Low & Normal & Normal & Low tension & Moderate tension & High tension \\
\hline & Moderate & Low tension & Low tension & Moderate tension & High tension & Disruption \\
\hline & High & Low tension & Moderate tension & High tension & High Tension & Disruption \\
\hline & Very High & Moderate tension & High tension & Disruption & Disruption & Disruption \\
\hline
\end{tabular}

Table 11. Impact ranking of threat events and vulnerabilities.

\begin{tabular}{ccccc}
\hline \multirow{2}{*}{ Threat Event } & \multicolumn{2}{c}{ RCP 2.6 } & \multicolumn{2}{c}{ RCP 8.5 } \\
\cline { 2 - 5 } & $\mathbf{2 0 3 1 - 2 0 5 0}$ & $\mathbf{2 0 8 1 - 2 1 0 0}$ & $\mathbf{2 0 3 1 - 2 0 5 0}$ & 2081-2100 \\
\hline Seasonal flows decline in Winnipeg River Basin & Moderate & Moderate & Moderate & High \\
Multi-year flows decline in Winnipeg River Basin & Disruption & Disruption & Disruption & Disruption \\
Season flows decline in Saskatchewan River Basin & Normal & Normal & Normal & Low \\
Multi-year flows decline in Saskatchewan River Basin & Low & Low & Low & High \\
\hline
\end{tabular}

\subsection{Likelihood}

Each threat event is associated with a likelihood, which can be expressed both qualitatively and quantitatively; Table 12 lists the IPCC likelihood rankings.

Table 12. Likelihood rankings.

\begin{tabular}{cc}
\hline Qualitative & Quantitative \\
\hline Virtually certain & $99-100 \%$ \\
Extremely likely & $95-100 \%$ \\
Very likely & $90-100 \%$ \\
Likely & $66-100 \%$ \\
About as likely as not & $33-66 \%$ \\
Unlikely & $0-33 \%$ \\
Very unlikely & $0-10 \%$ \\
Extremely unlikely & $0-5 \%$ \\
Exceptionally unlikely & $0-1 \%$ \\
\hline
\end{tabular}

We base the likelihood on past flows and changes in temperature and precipitation in each RCP; these are listed in Table 13.

Table 13. Likelihood of threat events in RCP 2.6 and RCP 8.5.

\begin{tabular}{ccccc}
\hline Threat Event & \multicolumn{2}{c}{ RCP 2.6 } & \multicolumn{2}{c}{ RCP 8.5 } \\
\cline { 2 - 5 } & 2031-2050 & $\mathbf{2 0 8 1 - 2 1 0 0}$ & $\mathbf{2 0 3 1 - 2 0 5 0}$ & Ver1-2100 Likely \\
\hline $\begin{array}{c}\text { Seasonal flows decline in Winnipeg River } \\
\text { Basin (WRB-S) }\end{array}$ & About as likely as not & Likely & Likely & Likely \\
$\begin{array}{c}\text { Multi-year flows decline in Winnipeg River } \\
\text { Basin (WRB-M) }\end{array}$ & Unlikely & About as likely as not & About as likely as not & Virtually certain \\
$\begin{array}{c}\text { Seasonal flows decline in Saskatchewan } \\
\text { River Basin (SRB-S) }\end{array}$ & Likely & Extremely likely & Extremely likely & Virtually certain \\
$\begin{array}{c}\text { Multi-year flows decline in Saskatchewan } \\
\text { River Basin (SRB-M) }\end{array}$ & Very Likely & Very likely & Very likely & \\
\hline
\end{tabular}




\subsection{Risk}

The energy security risk to the availability of power from the NRHP is determined from the Impact (Table 11) and the Likelihood (Table 13) of each threat event to the flows from the Winnipeg or Saskatchewan River Basins. We show this graphically in Figure 12 for RCP 2.6 and RCP 8.5 and two timeframes, 2031-2050 and 2081-2100. The risks reflect the contribution of the two basins to the NRHP's water supply (Table 4).

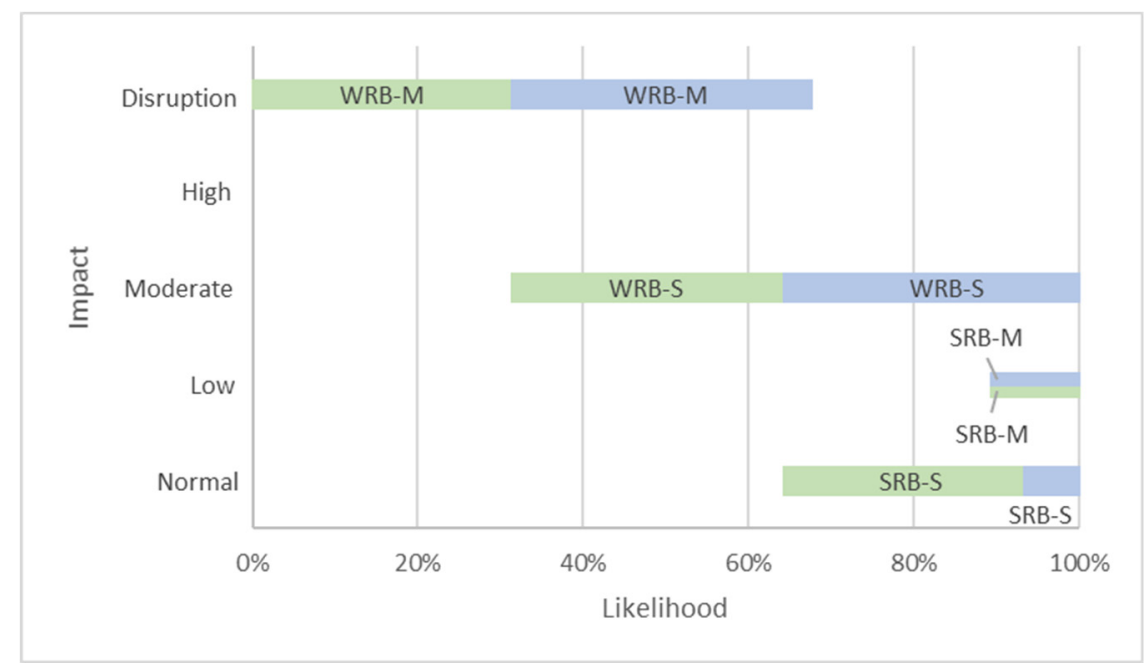

RCP 2.6.

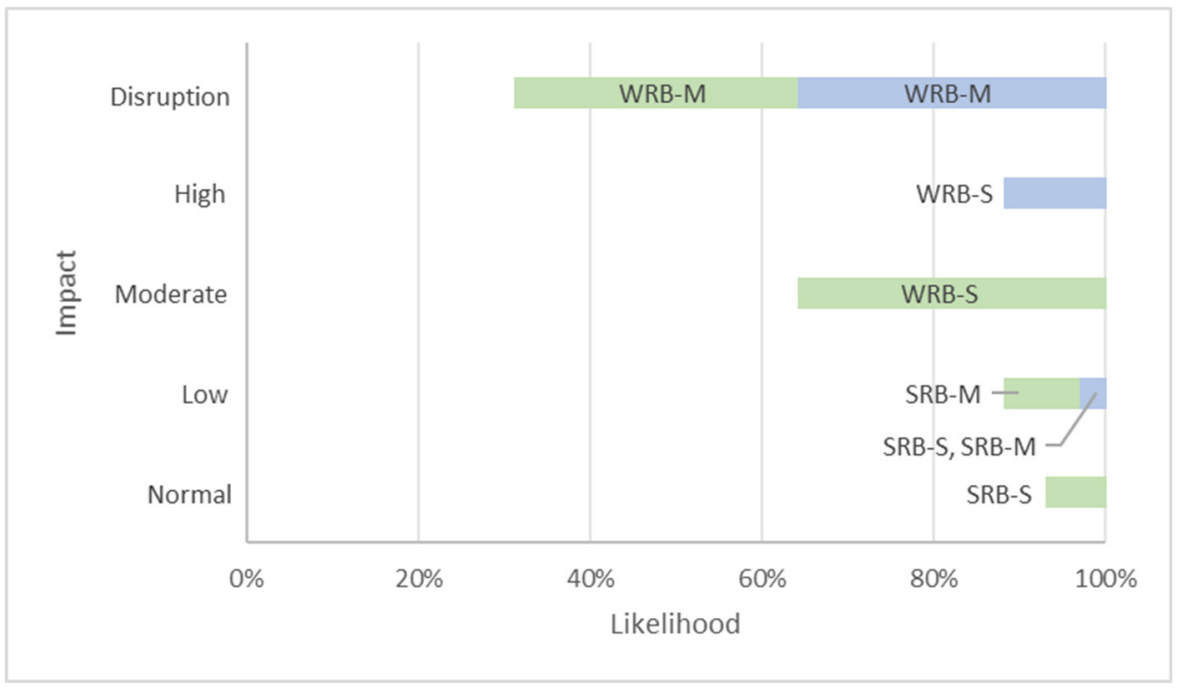

RCP 8.5.

Figure 12. Graphs of possible risks to the availability of water supply to the Nelson River Hydroelectric Project for RCP 2.6 and RCP 8.5. (WRB: Winnipeg River Basin; SRB: Saskatchewan River Basin; '-S': Seasonal; '-M': Multi-year; "1: 2031-2050; : 2081-2100).

For example, in RCP 2.6, the risk is About as likely as not (33-66\%) of a moderate impact to the availability of power from the NRHP caused by seasonal changes to the Winnipeg River Basin's (WRB-S, green) flow for 2031-2050; this increases to Likely (66-100\%) risk of a moderate impact between 2081 and 2100 (WRB-S, blue).

In RCP 8.5, the risk to the availability of power from a decline in multi-year from the Saskatchewan River Basin increases from a Very likely (90-100\%) low-impact risk in 2031-2050 (SRB-M, green) to becoming a Virtually certain (99-100\%) low-impact risk in 2081-2100 (SRB-M, blue).

When the two charts are taken together, the difference in risk to the availability of power from declines in the two basins becomes evident. In 2081-2100, the Likely (66-100\%) moderate 
impact risk of seasonal change to Winnipeg River Basin flows in RCP 2.6 (WRB-S, blue) is a Very likely (90-100\%) high-impact risk in RCP 8.5 (WRB-S, blue). This is a clear indication that emissions-reduction actions, such as reduction, replacement, and restructuring, are needed globally to protect energy systems such as Manitoba Hydro's NRHP.

\section{Discussion}

The example of the risks to the Nelson River Hydroelectric Project shows the utility of using the risk analysis tool with the energy security methods, since it offers a uniform stepwise approach to answer fundamental questions regarding the risks of global heating to energy systems and their energy security.

The three methods for determining energy security risks to an energy system through the example of the Nelson River Hydro Electric project have shown that they provide a solid framework to examine this. The framework is easy to use, is mostly qualitative, and does not require additional software, unlike some other models. This makes its application suitable for policymakers, scholars, and more advanced users that wish to systemically examine risks in an energy system.

The framework of methods also resulted in a visual representation of the risks under the scenarios. This can provide those interested with a quick overview of the outcomes of the analysis. Additionally, the method can be periodically applied when new data becomes available. In this case, the method was used to determine the risks to availability, but the model can also examine affordability, as Hughes et al. have done in their original work [29].

One of the downsides to the framework, especially in the threat section, is its intuitive nature with regard to global warming. The effect of global warming is neither fixed nor certain, and therefore the IPCC regularly updates its scenarios based on new data. This uncertainty makes it difficult to reach definitive conclusions on the risks that energy systems are exposed to and how exactly temperatures and precipitation will change annually and across seasons. By using Canada's Changing Climate Report [32] (p. 16), we relied on the expert judgement of its authors and the papers they cited. However, recent events in British Columbia indicate that global warming has an impact on energy systems.

This uncertainty means that it can be difficult to qualify a threat event. This uncertainty is applicable to every risk assessment method. In our framework, a user must make substantiated assumptions and demonstrate extensive knowledge of the energy system when making these assessments. This can be viewed as a weakness of the methods. However, users should acknowledge this uncertainty and take measures to limit the impact of this uncertainty. Still, this limitation can have a minimal impact on the assessment.

\section{Conclusions}

This paper has introduced a set of methods that can be used to systematically determine the risks to an energy system by considering the processes within the system and the energy sources it uses, the entities that it serves, its interactions with the environment, and the regulations required to manage it. From this, the second set of methods was described, which show how the energy security of the system could be determined and how its energy security could be maintained and improved through policy actions that reduce energy use, replace processes or energy flows, or restructure part of the energy system. The energy security dimensions, availability, affordability, and acceptability, were explained in terms of the levels of stress that could affect the energy system and its end-users. This was followed by the explanation of a customizable generic energy security risk model, which can be used to determine the risk of an entity's energy security, as the example of Manitoba Hydro's Nelson River Hydroelectric Project has demonstrated.

To illustrate the applicability of the methods, one of the possible threats of global heating to the energy security of Manitoba Hydro's Nelson River Hydroelectric Project was discussed. In the example, the possible risk to the availability of power in Manitoba caused by changes in temperature and precipitation due to global heating in two IPCC scenarios (RCP 2.6 and RCP 8.5 ) was considered. The example showed the utility of energy systems 
analysis by demonstrating the workings of the NRHP and its dependency on the Winnipeg River and Saskatchewan River Basins.

We believe that the graphical method of showing the risks of global heating on an energy system, such as was done with the NRHP and RCP 2.6 and 8.5, could help inform the public of the need for climate action. In the case of Manitoba Hydro and its customers, the reliance on carbon-neutral hydro power is a risk to its energy security.

Adapting the electricity system to this risk will require Manitoba Hydro to restructure parts of its system to reduce its vulnerabilities; for example, creating additional reservoirs in northern Manitoba to connect to the Nelson River, as was done with the Churchill River diversion. Wind and solar, which are both variable renewable energy sources, need an operating reserve to meet those periods when they are not available; hydroelectricity is seen as a natural, low-emissions source of power during those times. This would reduce the vulnerabilities of the system to drought. Adaptation can also occur with the end-user, for example, by using net-metering in conjunction with rooftop solar and battery storage.

Future research can expand our study on the Nelson River Hydro Electric Power, for example by applying the methods to Manitoba. To strengthen the applicability base of these methods, other cases can be examined.

Although the methods described in this paper can be applied to national or international energy systems, the example showed one of the benefits of working at the subnational scale since it enabled an analysis of one of the subsystems that contribute to Canada's national energy system. The availability of detailed studies of the possible impacts of global heating in Canada's regions enabled the resulting risk analysis. Although not part of the analysis, it also highlighted the importance of working towards large-scale, global emissions reduction if the risks of global heating seen to Manitoba's hydroelectric system and energy security are not to be repeated elsewhere.

Author Contributions: Conceptualization, L.H. and M.d.J.; methodology, L.H. and M.d.J.; software, L.H.; validation, L.H. and M.d.J.; formal analysis, L.H.; investigation, M.d.J.; resources, L.H.; data curation, L.H. and M.d.J.; writing—original draft preparation, L.H. and M.d.J.; writing-review and editing, M.d.J.; visualization, L.H. All authors have read and agreed to the published version of the manuscript.

Funding: This research received no external funding.

Acknowledgments: The authors would like to thank the three anonymous reviewers for their insightful suggestions.

Conflicts of Interest: The authors declare no conflict of interest.

\section{References}

1. NASA. Exceptional Heat Hits Pacific Northwest. 25 June 2021. Available online: https:/ / earthobservatory.nasa.gov /images/14 8506/ exceptional-heat-hits-pacific-northwest (accessed on 14 July 2021).

2. Isai, V.; Bilefsky, D.; Hubler, S. Deaths Spike as Heat Wave Broils Canada and the Pacific Northwest. 12 July 2021. Available online: https:/ / www.nytimes.com/2021/06/30/world/canada/bc-canada-heat-wave.html (accessed on 14 July 2021).

3. Henson, B. Northwest U.S., British Columbia Brace for Historic, Record-Melting Heat. 24 June 2021. Available online: https: //yaleclimateconnections.org/2021/06/northwest-u-s-british-columbia-brace-for-historic-record-melting-heat/ (accessed on 14 July 2021).

4. Borenstein, S. Study: Northwest Heat Wave Impossible without Climate Change. 8 July 2021. Available online: https:/ phys.org/ news /2021-07-northwest-impossible-climate.html (accessed on 14 July 2021).

5. Sjoukje, P.; Kew, S.; van-Oldenborgh, G.; Yang, W.; Vecchi, G.; Anslow, F.; Li, S.; Seneviratne, S.; Luu, L.; Arrighi, J.; et al. Rapid attribution analysis of the extraordinary heatwave on the Pacific Coast of the US and Canada June 2021. World Weather. Attrib. 2021. Available online: https:/ / www.ecodebate.com.br/wp-content/uploads/2021/07/20210707-rapid-attribution-analysisof-the-extraordinary-heatwave-on-the-pacific-coast-of-the-us-and-canada-june-2021.pdf (accessed on 15 August 2021).

6. Hughes, L. The effects of event occurrence and duration on resilience and adaptation in energy systems. Energy 2015, 84, 443-454. [CrossRef]

7. CBS. Big Oil Asks Government to Protect Its Texas Facilities from Climate Change. Available online: https://www.cbsnews.com/ news/texas-protect-oil-facilities-from-climate-change-coastal-spine/ (accessed on 22 August 2018). 
8. Cruz, A.M.; Krausmann, E. Vulnerability of the oil and gas sector to climate change and extreme weather events. Clim. Chang. 2013, 121, 41-53. [CrossRef]

9. Katopodis, T.; Sfetsos, A. A Review of Climate Change Impacts to Oil Sector Critical Services and Suggested Recommendations for Industry Uptake. Infrastructures 2019, 4, 74. [CrossRef]

10. Seneviratne, S.; Nicholls, N.; Easterling, D.; Goodess, C.; Kanae, S.; Kossin, J.; Luo, Y.L.; Marengo, J.; McInnes, K.; Rahimi, M.; et al. Changes in Climate Extremes and Their Impacts on the Natural Physical Environment. Available online: https: //www.ipcc.ch/site/assets/uploads/2018/03/SREX-Chap3_FINAL-1.pdf (accessed on 20 August 2021).

11. Webber, M.E. Thirst for Power-Energy, Water and Human Survival; Yale University Press: New Haven, CT, USA, 2016 ; p. 235.

12. Gross, S. Republicans in Congress are Out of Step with the American Public on Climate. 10 May 2021. Available online: https://www. brookings.edu/blog/planetpolicy/2021/05/10/republicans-in-congress-are-out-of-step-with-the-american-public-on-climate/ (accessed on 14 July 2021).

13. Natalini, D.; Bravo, G.; Newman, E. Fuel riots: Definition, evidence and policy implications for a new type of energy-related conflict. Energy Policy 2020, 147, 111885. [CrossRef]

14. Grossmann, K. Using conflicts to uncover injustices in energy transitions: The case of social impacts of energy efficiency policies in the housing sector in Germany. Glob. Transit. 2019, 1, 148-156. [CrossRef]

15. Li, Y.; Ye, W.; Wang, M.; Yan, X. Climate change and drought: A risk assessment of crop-yield impacts. Clim. Res. 2009, 39, 31-46. [CrossRef]

16. Zhao, J.; Zhang, Q.; Zhu, X.; Shen, Z.; Yu, H. Drought risk assessment in China: Evaluation framework and influencing factors. Geogr. Sustain. 2020, 1, 220-228. [CrossRef]

17. Field, C.; Barros, V.; Stocker, T.; Dahe, Q. Managing the Risks of Extreme Events and Disasters to Advance Climate Change Adaptation; Cambridge University Press: Cambridge, UK, 2012.

18. Christensen, N.S.; Wood, A.W.; Voisin, N.; Lettenmaier, D.P.; Palmer, R.N. The Effects of Climate Change on the Hydrology and Water Resources of the Colorado River Basin. Clim. Chang. 2004, 62, 337-363. [CrossRef]

19. Zapata, S.; Castaneda, M.; Garces, E.; Franco, C.J.; Dyner, I. Assessing security of supply in a largely hydroelectricity-based system: The Colombian case. Energy 2018, 156, 444-457. [CrossRef]

20. Shadman, F.; Sadeghipour, S.; Moghavvemi, M.; Saidur, R. Drought and energy security in key ASEAN countries. Renew. Sustain. Energy Rev. 2016, 53, 50-58. [CrossRef]

21. Jääskeläinen, J.; Veijalainen, N.; Syri, S.; Marttunen, M.; Zakeri, B. Energy security impacts of a severe drought on the future Finnish energy system. J. Environ. Manag. 2018, 217, 543-554. [CrossRef] [PubMed]

22. Axon, C.; Darton, R. Sustainability and risk-A review of energy security. Sustain. Prod. Consum. 2021, 27, 1195-1204. [CrossRef]

23. Gupta, E. Oil vulnerability index of oil-importing countries. Energy Policy 2008, 36, 1195-1211. [CrossRef]

24. Jun, E.; Kim, W.; Chang, S.H. The analysis of security cost for different energy sources. Appl. Energy 2009, 86, 1894-1901. [CrossRef]

25. Sheikh, S.; Komaki, M.; Malakooti, B. Integrated risk and multi-objective optimization of energy systems. Comput. Ind. Eng. 2015, 90,1-11. [CrossRef]

26. Ang, B.; Choong, W.; Ng, T. A framework for evaluating Singapore's energy security. Appl. Energy 2015, 148, 314-325. [CrossRef]

27. Zhang, H.-Y.; Ji, Q.; Fan, Y. An evaluation framework for oil import security based on the supply chain with a case study focused on China. Energy Econ. 2013, 38, 87-95. [CrossRef]

28. Winzer, C. Conceptualizing energy security. Energy Policy 2012, 46, 36-48. [CrossRef]

29. Hughes, L.; de Jong, M.; Wang, X. A Generic Method for Analyzing the Risks to Energy Systems. Appl. Energy 2016, 180, 895-908. [CrossRef]

30. Manitoba Hydro, Generating Stations. Available online: https://www.hydro.mb.ca/corporate/facilities/generating_stations / (accessed on 23 February 2020).

31. Natural Resources Canada, Electricity Facts. 6 October 2020. Available online: https://www.nrcan.gc.ca/science-and-data/dataand-analysis/energy-data-and-analysis/energy-facts/electricity-facts/20068 (accessed on 31 August 2021).

32. Bush, E.; Flato, G. Canada's Changing Climate Report. 2019. Available online: https://www.nrcan.gc.ca/maps-tools-publications / publications/climate-change-publications / canada-changing-climate-reports/canadas-changing-climate-report/21177 (accessed on 16 November 2019).

33. IPCC. Climate Change 2014. In Mitigation of Climate Change. Contribution of Working Group III to the Fifth Assessment Report of the Intergovernmental Panel on Climate Change; Edenhofer, O., Pichs-Madruga, R., Sokona, Y., Minx, J.C., Farahani, E., Seyboth, K., Adler, A., Baum, I., Brunner, S., Eickemeier, P., et al., Eds.; Cambridge University Press: Cambridge, UK; New York, NY, USA, 2014.

34. Manitoba Hydro. Power Sale Arrangements. Available online: https://www.hydro.mb.ca/corporate/electricity_exports/power_ sale_arrangements / (accessed on 31 August 2021).

35. Manitoba Hydro. Electricity Exports. Available online: https://www.hydro.mb.ca/corporate/electricity_exports/ (accessed on 31 August 2021).

36. Hughes, L. A generic framework for the description and analysis of energy security in an energy system. Energy Policy 2012, 42, 221-231. [CrossRef]

37. IEA. World Energy Outlook 2019, October 2019. Available online: https:/ / www.iea.org/reports/world-energy-outlook-2019 (accessed on 20 November 2019). 
38. EIA. Residential Energy Consumption Survey (RECS): State Fact Sheets on Household Energy Use. 13 August 2013. Available online: https://www.eia.gov/consumption/residential/reports/2009/state_briefs/ (accessed on 9 January 2020).

39. AGA. How Does the Natural Gas Delivery System Work? 2020. Available online: https://www.aga.org/natural-gas/delivery/ how-does-the-natural-gas-delivery-system-work- / (accessed on 8 January 2020).

40. IEC. Efficient Electrical Energy Transmission and Distribution. 2007. Available online: http://web.vdw.co.za/Portals/15/Documents/ Presentations/transmission.pdf (accessed on 8 January 2020).

41. Esfahani, A.N.; Moghaddam, N.B.; Maleki, A.; Nazemi, A. The knowledge map of energy security. Energy Rep. 2021, 7, 3570-3589. [CrossRef]

42. Gracceva, F.; Zeniewski, P. A systemic approach to assessing energy security in a low-carbon EU energy system. Appl. Energy 2014, 123, 335-348. [CrossRef]

43. Goulder, L.H.; Parry, I.W.H. Instrument Choice in Environmental Policy. Rev. Environ. Econ. Policy 2008, 2, 152-174. [CrossRef]

44. EIA. Short-Term Energy Outlook. 12 February 2019. Available online: https://www.eia.gov/outlooks/steo/pdf/steo_full.pdf (accessed on 14 February 2019).

45. Statistics Canada. Table 25-10-0015-01 Electric Power Generation, Monthly Generation by Type of Electricity. 7 July 2021. Available online: https: / / www150.statcan.gc.ca/t1/tbl1/en/tv.action?pid=2510001501 (accessed on 24 February 2020).

46. Keeyask. Keeyask Hydropower Limited Partnership. Available online: https://keeyask.com (accessed on 25 February 2020).

47. Manitoba Hydro. Keeyask Generating Station. Available online: https://www.hydro.mb.ca/projects/keeyask/ (accessed on 25 February 2020).

48. Manitoba Hydro. Appendix 7.2-Range of Resource Options. August 2013. Available online: https://web.archive.org/web/2013 1231001218/http://hydro.mb.ca/projects/development_plan/bc_documents/appendix_07_2_range_of_resource_options.pdf (accessed on 6 March 2020).

49. Manitoba Hydro. Lake Winnipeg Regulation. July 2014. Available online: https://www.hydro.mb.ca/docs/regulatory_affairs/ pdf/lake_wpg_regulation/lwr_complete_report.pdf (accessed on 24 February 2020).

50. Manitoba Hydro. Churchill River Diversion. Available online: https://www.hydro.mb.ca/corporate/facilities/water_levels/ churchill_river_diversion/ (accessed on 1 March 2020).

51. Zubrycki, K.; Roy, D.; Osman, H.; Lewtas, K.; Gunn, G.; Grosshans, R. Large Area Planning in the Nelson-Churchill River Basin (NCRB): Laying a foundation in northern Manitoba. November 2016. Available online: https://www.iisd.org/sites/default/ files / publications / large-area-planning-nelson-churchill-river-basin-full-report.pdf (accessed on 1 March 2020).

52. Sauchyn, D.; Bedoya, M.; González-Reyes, Á.; Muñoz, J.J.V.U.A. El Niño Tele-Connections and Their Role in Drought; Prairie Adaptation Research Collaborative: Regina, Saskatchewan, 2019.

53. Alberta Water. History of Drought in Alberta. 2019. Available online: https://albertawater.com/history-of-drought-in-alberta (accessed on 28 February 2020).

54. ECCC. Monthly Discharge Data for Saskatchewan River at Grand Rapids (05KL001) [MB]. 3 February 2020. Available online: https: / / wateroffice.ec.gc.ca / report/historical_e.html?stn=05KL001\&dataType=Monthly\&parameterType=Flow\&year=20 18\&mode $=$ Table (accessed on 1 March 2020).

55. ECCC. Monthly Discharge Data for Winnipeg River at Pine Falls Generating Station (05PF069) [MB]. 3 February 2020. Available online: https: / / wateroffice.ec.gc.ca/report/historical_e.html?stn=05PF069\&dataType=Monthly\&parameterType=Flow\&year= 2018\&mode $=$ Table\&page $=$ historical (accessed on 1 March 2020).

56. UNFCCC. Paris Agreement (Annex), United Nations Framework Convention on Climate Change COP-21; UNFCCC: Paris, France, 2015.

57. UN. Emissions Gap Report 2019; UN Environment Programme: Nairobi, Kenya, 2019.

58. Van Vuuren, D.; Edmonds, J.; Kainuma, M.; Riahi, K.; Thomson, A.; Hibbard, K.; Hurtt, G.; Kram, T.; Krey, V.; Lamarque, J.-F.; et al. The representative concentration pathways: An overview. Clim. Chang. 2011, 109, 5-31. [CrossRef]

59. IIASA. RCP Database (Version 2.0), February 2020. Available online: http://tntcat.iiasa.ac.at/RcpDb/dsd?Action=htmlpage\& page $=$ compare (accessed on 20 August 2021).

60. Clarke, G.K.; Jarosch, A.H.; Anslow, F.S.; Radić, V.; Menounos, B. Projected deglaciation of western Canada in the twenty-first century. Nat. Geosci. 2015, 8, 372-377. [CrossRef]

61. Mikle, C.; Fagre, D. Glacier recession since the Little Ice Age: Implications for water storage in a Rocky Mountain landscape. Arct. Antarct. Alp. Res. 2019, 51, 280-289. [CrossRef]

62. Pelto, M. Hydropower, North Cascade Glacier Climate Project. Available online: https://glaciers.nichols.edu/glacier-runoffhydropower/ (accessed on 25 August 2021).

63. Castellazzi, P.; Burgess, D.; Rivera, A.; Huang, J.; Longuevergne, L.; Demuth, M. Glacial Melt and Potential Impacts on Water Resources in the Canadian Rocky Mountains. Water Resour. Res. 2019, 55, 10191-10217. [CrossRef]

64. Wikimedia, Palliser's Triangle, 26 November 2016. Available online: https://commons.wikimedia.org/wiki/File:Palliser\%27s_ Triangle_map.png (accessed on 6 March 2020).

65. Crockett, J.L.; Westerling, A.L. Greater Temperature and Precipitation Extremes Intensify Western U.S. Droughts, Wildfire Severity, and Sierra Nevada Tree Mortality, American Mereorological Society, January 2018. Available online: https://journals.ametsoc. org/doi / full/10.1175/JCLI-D-17-0254.1 (accessed on 28 February 2020). 